\title{
Seferihisar'ın Ekonomik ve Mali Yapısı Üzerinden Sakin Şehir Uygulamalarına İlişkin Bir İnceleme*
}

\begin{abstract}
Mehmet TUNÇER ${ }^{1}$
Abdurrahman OLGUN ${ }^{2}$

ÖZ: Cittaslow Hareketi'nin temelleri 1999 yılında Italya'nın Orvieto kentinde atılmıştır. Bu hareket, küreselleşmenin getirdiği standartlaşmanın sonucu olarak hızl ve tüketime dayalı bir hayatın egemen olduğu şehir yaşamına farklı bir alternatif olarak ortaya çıkmıştır. Bu çalışmada, öncelikle, yerel özellikleri koruyarak turizm başta olmak üzere belirli alanlarda kentsel yaşama önemli katkıları olan Sakin Şehir Hareketi tanıtılmıştır. İkinci olarak, Türkiye’nin ilk Sakin Şehri olan Seferihisar örneğinde bu hareketin şehirlere ekonomik ve mali açıdan să̆ladı̆̆ veya sağlayabileceği katkılar araştırılmıştır. Çalışmada; özellikle organik tarım, turizm, kadın istihdamı ve yenilebilir enerji gibi alanlarda Seferihisar'da görülen olumlu gelişmelerin, daha kapsamll bir şekilde Türkiye'de bugün var olan ve gelecekte bu sisteme dahil olabilecek diğer Sakin Şehirlerde de yaşanabileceği sonucuna varılmıştır. Çalışmada ayrıca, devletin Sakin Şehir uygulamalarını ve bu kapsamdaki projeleri destekleyici ve düzenleyici yönde özel yasalar ve özel teşvik programları hazırlamasının önemi vurgulanmıştır.
\end{abstract}

Anahtar Kelimeler: Sakin Şehir, Yavaş Yemek, Seferihisar

Jel Sinıflandırması: H7, O1, Z32

\section{A Review of Cittaslow Practices on the Economic and Fiscal Structure of Seferihisar}

\begin{abstract}
The foundations of the Cittaslow Movement were laid in 1999 in Orvieto, Italy. This movement has emerged as a different alternative to urban life, where a rapid and consumptionbased life predominates as a result of the standardization brought by globalization. In this study, firstly Cittaslow Movement, which is an important contribution to urban life in particular areas, especially tourism, by preserving local characteristics, was introduced. Secondly, in the case of Seferihisar, the first Cittaslow of Turkey, the contributions that this movement provided or could provide in economic and fiscal terms were investigated. In the study; positive developments in Seferihisar especially in fields such as organic agriculture, tourism, women's employment and renewable energy have come to the conclusion that there can be more extensively in other Cittaslow cities that exist in Turkey today and can be included in this system in the future. It also emphasized the importance of the government's implementation of Cittaslow and the preparation of special legislation and special incentive programs in supportive and regulatory frameworks for projects in this context.
\end{abstract}

Key Words: Cittaslow, Slow Food, Seferihisar

Jel Classification: $\mathrm{H7}, \mathrm{Ol}, \mathrm{Z32}$

Geliş Tarihi / Received: 13.03.2017

Kabul Tarihi / Accepted: 10.04.2017

\footnotetext{
* Bu çalışma, Doç. Dr. Mehmet Tunçer'in danışmanlığında hazırlanmış ve KTÜ Sosyal Bilimler Enstitüsü Maliye Anabilim Dalı'nda 2016 yılında kabul edilmiş olan Abdurrahman Olgun'un "Yavaş Şehir (Cittaslow): Seferihisar Örneğiyle Ekonomik ve Mali Yapı" isimli Yüksek Lisans Tezinden yararlanılarak ve güncellenerek hazırlanmıştır.

${ }^{1}$ Doç.Dr., Karadeniz Teknik Üniversitesi, İİBF, Maliye Bölümü, mehmettuncer1@yahoo.com

${ }^{2}$ Yüksek Lisans Öğrencisi, Karadeniz Teknik Üniversitesi, SBE, olgunapo.61@gmail.com
} 


\section{Giriș}

Yavaş Şehir Akımı, küreselleşmenin getirdiği standartlaşmaya karşı yerel özellikleri korumayı amaç edinen bir hareket olarak 1999 yılında İtalya'da başlamıştır. Bu akım; hızlı ve tüketime dayalı bir hayatın egemen olduğu şehir yaşamına farklı bir alternatif olarak ortaya çıkmıştır.

Dünya nüfusunun her geçen gün daha da artması şehirlerdeki yaşam kalitesini de olumsuz etkilemektedir. Bu olumsuz gidişe Yavaş Şehir Hareketi çerçevesinde az da olsa bir çözüm bulunmaya çalışılmaktadır. Buna göre, bu akımın hız tutkunu insanların ortaya çıkardığı sorunların çözümünde tek başına kapsayıcı bir çözüm olmasa da belirli başarılar elde ettiği görülmektedir. Bu çalışmada Yavaş Şehir uygulamalarının söz konusu olumlu etkileri Türkiye'de bu harekete ilk üye olan Seferihisar örneği üzerinden incelenmeye çalışılacaktır.

Çalışmada öncelikle Sakin Şehir kavramına ilişkin bilgi verilecektir. Buna göre, Yavaş Şehir Hareketi'nin ortaya çıkışı, felsefesi, üyelik koşulları ve olumlu/olumsuz yönleri açıklanacaktır. İkinci olarak, Yavaș Şehir Akımı'nın Seferihisar çerçevesinde şehirlere ekonomik ve mali açıdan sağladığı ya da sağlayabileceği katkılar araştırılacaktır. Bu çerçevede ilk olarak Seferihisar'ın nüfus ve ekonomik yapısındaki gelişmelerle birlikte vergi mükellefi sayılarındaki değişim incelenecektir. Daha sonra Seferihisar'daki tarım, sanayi, turizm, ticaret ve yatırım, kadın istihdamı, kayıtdışı ekonomi ve yenilebilir enerji alanındaki gelişmeler incelenerek, Yavaş Şehir uygulamasının bunlar üzerindeki etkileri araştırılacaktır. Çalışmada son olarak, Sakin Şehir Hareketi'ne, Seferihisar örneğine ve Türkiye'ye yönelik çeşitli tespit ve öneriler yapılacaktır.

\section{Sakin Şehir Kavramı, Ortaya Çıkışı ve Özellikleri}

İtalyanca "citta" ve İngilizce "slow" kelimelerinin birleşmesiyle oluşan Cittaslow, Yavaş Şehir veya Sakin Şehir anlamına gelmektedir. Türkiye'de bugün daha çok Yavaş Şehir kullanılsa da, Sakin Şehir kullanımı gittikçe yaygınlaşmaktadır. Bu çalışmada her üç kavram da kullanılmaktadır.

Yavaş Şehir Akımı, hızlı ve modern hayatı eleştiren, hayatın çeşitli alanlarında hız ve modern tüketim çılgınlığını azaltmayı amaçlayan bir harekettir. Bu akımın şehirlerin kalkınmasında ve gelişmesinde önemli katkı sağlaması beklenmektedir. $\mathrm{Bu}$ yönüyle Yavaş Şehir Hareketi'nin, ekonomik açıdan istediği seviyeye ulaşamayan ancak belirli özelliklere sahip şehirlere önemli katkılar sağlaması beklenmektedir.

Cittaslow Birliği, küreselleşmenin yarattığı homojen mekânlardan biri olmak istemeyen, yerel kimliğini ve özelliklerini muhafaza ederek dünya sahnesinde yer almak isteyen şehirlerin katıldığı uluslararası bir birliktir (Cittaslow Seferihisar, 2015). Kent insanının yaşam kalitesinin, özellikle yiyecek kültürü göz önünde 
bulundurularak artırılmak istenmesi yavaş kentlerin temel felsefesini oluşturmaktadır (Miele, 2008: 135).

Yavaş Şehir Hareketi'nin ilk olarak, 1986 yılında Roma'daki McDonalds açılışının Carlo Petrini önderliğindeki grup tarafından tabaklar dolusu İtalyan makarnası firlatılarak protesto edilmesiyle başladığı belirtilmektedir. Hızlı yemeğe bir tepki olarak "Yavaş Yemek" (Slow Food) denilen ve doğaçlama şekillenen bu karşı hareket giderek yaygınlaşmıştır. Bu hareket ilerleyen yıllarda yalnızca gıda üzerine değil; yaşam, yolculuk, eğitim, okuma, para ve başka alanlarda da ortak bir yavaşlık felsefesinden beslenen bir akım halini almıştır (Şahinkaya, 2010).

Cittaslow Birliği 15 Ekim 1999 tarihinde İtalya'nın Orvieto kentinde, ChiantiOrvieto-Bra ve Positano kentlerinin belediye başkanları ve Slow Food Hareketi'nin kurucusu Carlo Petrini tarafından imzalanan Yavaş Şehirler Sözleşmesi'yle resmen kurulmuştur (Radstrom, 2011: 90 ve Karakurt, 2013: 215 127).

Yavaş Şehir Akımı başlangıçta İtalya'daki şehirlerde ortaya çıkmasına rağmen, ilerleyen dönemlerde dünyaya da yayılarak önemli bir harekete dönüşmüştür. $\mathrm{Bu}$ anlamda dünyada bu hareketin, adının aksine çok hızlı bir gelişme gösterdiği söylenebilir.

Kurulduğu 1999 y1lında 4 üyesi olan Cittaslow'un, Şubat 2017 itibariyle 30 ülkeden 230'u aşkın üyesi vardır (Cittaslow, 2017-1). Bu ülkelerden biri olan Türkiye'deki Yavaş Şehir sayısı, 3-5 Şubat 2017 tarihleri arasında Şavşat'ta yapılan Türkiye Koordinasyon Kurulu Toplantısı'nda yeni üye olarak kabul edilen Eğirdir, Göynük ve Gerze ile birlikte 14'e yükselmiştir (Cittaslow, 2017-2).

Yavaş Hareketi hızlı modern hayatı eleştiren ve hayatın birçok alanlarında (yemeiçme biçimi, yaşam, ekonomik hayat, trafik, ilişkiler vb.) hız ve modern tüketim kalıplarını dönüştürecek bir kültürel değişimi savunan toplumsal harekettir (Sezgin ve Ünüvar, 2011: 107).

Cittaslow demek; yerel tatları ve sanatları sadece eskilerin hatırlayabildiği kavramlar olmaktan çıkarmak, bunları gelecek nesillerle paylaşmaktır. En önemlisi ise, Cittaslow bir şehrin, dünyada binlerce birbirinin aynı şehirden farklılaştırılmasıdır (Cittaslow Seferihisar, 2015).

Yavaş Şehir Akımı, şehirlerin hangi önemli özelliğe sahip olduklarının belirlenmesi ve bu özelliklerini korumaya yönelik strateji geliştirilmesi için yol gösteren bir harekettir. Buna göre Yavaş Şehir Hareketi; şehrin dokusunun, renginin, müziğinin ve hikâyesinin uyum içinde, şehir sakinlerinin ve şehri ziyaret edenlerin zevk alabilecekleri bir hızda yaşanması anlamına gelmektedir (Sezgin ve Ünüvar, 2011: 128).

Hızlı ve yavaş felsefelerinin karşılaştırıldığı çalışmalarda hız sözcügü büyük kent sistemleriyle örneklenmiştir. Hız; düşük kalitede, sürdürülebilirliği olmayan, 
eşitsiz bir yaşamın olduğu, adeta kopyalanmış gibi birbirlerinin aynı yapılar ve yaşam tarzlarından oluşan, yerel tarih ve kültürel özelliklerin göz ardı edildiği yapıların oluşumuna neden olmaktadır. Buna karşın, yavaşlık ile; kişiye özgü üretimin ve tüketimin sağlandığı, kişilere birden fazla alternatiften birini seçme şansının sunulduğu, sürdürülebilirliğin desteklendiği, yüksek kaliteli üretimin yapıldı̆̆ 1 ve yerel ve geleneksel özelliklerin dikkate alındığı yapılar ifade edilmektedir (Kostulska vd., 2011: 186-192).

Yavaş Hareketi, dünyanın her bölgesinin yerel kültürünü korumasını ve sahip çıkmasını savunmakta, küreselleşmeyi reddetmemekle birlikte özgünlüğg̈ ve küreselleşmenin olumsuz etkilerini vurgulamaktadır. Buna göre Yavaş Hareketi; hıza karşı bir reaksiyon olmakla birlikte saate bakmaktan ve sürekli aceleden kaçınmak, yaşam kalitesini yükseltmek ve zamanın hızını kesmek amacıyla ortaya çıkan hareketleri kapsamaktadır (Caffyn, 2007).

Yavaş Şehir Hareketi, küçük şehirlerde yaşam kalitesinin sürdürülmesi yönünde çalışmalar yapan bir ağ oluşturmuştur. Buna göre Yavaş Şehir Konsepti; çevrenin korunması, yerel mal ve ürünleri teşvik ve her bir şehir için kendine özgü, eşsiz bir sürdürülebilirliği kapsamaktadır. Yavaş Şehir Hareketi, şehirlerde yaşam kalitesinin artırılmasının sağlanmasının yanında; şehirlerin aynılaşmasına da karşı çıkmaktadır. Buna göre; bir şehrin eşsizliği ve kültürel çeşitliliği Cittaslow'un temel değerleridir (Sustainable Cities, 2015).

Yavaş Şehir Hareketi'nin ana karakteristiği şüphesiz yavaşlık, sakinlik olmuştur. Ancak, bu yavaşlık yanlış kurgulanıp teknolojiye karşı bir duruş olarak algılanmamalıdır. Aksine Yavaş Şehir Hareketi'nin teknolojiyi de kullanarak gelişmekte olduğu görülmektedir.

Milan Kundera (2008: 38-39), yavaşlık ve hız arasındaki farkı açıklarken "yavaşlık ile hatırlama, hız ile unutma arasında gizli bir ilişki vardır" diyerek, anıların daha yoğun yaşanmasının önemine vurgu yapmaktadır. $\mathrm{Bu}$ anlamda, hayatımızda gerçekleştirdiğimiz eylemlerin daha tatmin edici ve dengeli bir şekilde olması ve hayatın doğru hızda yaşanması önerilmektedir.

Günümüz toplumlarına tarihte görülmemiş ölçüde hız kazanan teknolojik yenilikler sunulmaktadır. Bu yenilikler, bir yandan binlerce $\mathrm{km}$ mesafelerin aşılmasına ve farklı ülkelerde yaşayan insanların görüntülü konuşma yapabilmelerine imkân sağlamaktadır. Diğer taraftan, mekânların ortadan kaybolduğu ya da artık anlamını yitirdiği gibi bir izlenim oluşmaktadır (Gottscholk, 1999: 311). Yavaşlık, var olan bu yapıyı insanların lehine çevirebilecek alternatif bir yaklaşım olarak karşımıza çıkmaktadır. Yavaşlık, insanlara günlük yaşamlarını oluşturan unsurlarla ilgili zamanlarını daha dikkatli kullanması gerektiğini belirtmektedir. Buna göre, yavaşlığın temeli, sahip olunan zamanın önem taşıyan işler için kullanılmasıdır (Parkins, 2004: 363).

Yavaş Hareketi, yaşanılabilir şehirler hareketi ve benzer bağlantılı sürdürülebilirlik oluşumları çerçevesinde gelişen bir olgudur. $\mathrm{Bu}$ anlamda bu 
hareket, hız ve kültürel piyasalara tepki olarak bir meydan okumadır. Yavaş Hareketi özellikle Yavaş Yemek, Yavaş Şehirler ve Yavaş Trafik Hareketi şeklinde üç konu üzerinde yoğunlaşmıştır (Newman ve Jennings, 2008: 195). Ancak bu hareket yaşamın çeşitli alanlarına da uygulanmış ve bunun sonucunda Yavaş Ebeveynlik, Yavaş Sanat, Yavaş Politikalar, Yavaş Seyahat, Yavaş Tasarım ve Yavaş Okul şeklinde başka akımlar ortaya çıkmıştır (Wikipedia, 2015 ve Sezgin ve Ünüvar, 2011: 108).

Cittaslow'a giriş öncesinde şehirlerin bir değerlendirmeden geçmesi gerekmektedir. Bunun için öncelikle Cittaslow Birliği'ne başvuracak kentlerin nüfuslarının 50.000'den az olması ve kent yönetiminin Cittaslow felsefesiyle uyumlu olması gerekmektedir. Bunun dışında, Çevre Politikaları; Altyapı Politikaları; Kentsel Yaşam Kalitesi Politikaları; Tarımsal, Turistik, Esnaf ve Sanatkârlara Dair Politikalar; Misafirperverlik, Farkındalık ve Eğitim İçin Planlar; Sosyal Uyum ve Ortaklıklar şeklinde 7 başlık altındaki 70 tane kriter bulunmaktadır. Bir şehrin üyeliğe kabul edilebilmesi için, bu kriterler çerçevesinde yapılan öz değerlendirmeden \%50'sinin gerçekleştirilmiş olması gerekmektedir. Söz konusu şehirler, yerine getiremediği kriterlerle ilgili olarak da kendine hedefler belirlemeli ve bunları gerçekleştirmek için çalışmalıdır (Cittaslow Türkiye, 2017).

Yavaş Şehir Birliği'ne üye olabilmek için belirlenen kriterlere bakıldığında, bu hareketin özellikle küçük kentler için çok önemli bir kalite projesi olduğu söylenebilir. $\mathrm{Bu}$ akım ile birlikte üye şehirlerin kültür, ekonomi, barınma, teknoloji, ortak sorumluluk, çevre koruma ve sağlıklı gıda gibi konularda daha zengin bir yapıya kavuşması beklenmektedir. Aynı şekilde Sakin Şehir sayesinde pazarlama politikalarının kalitesi ve verimliliği geliştirilebilmekte ve turizm olanakları artırılabilmektedir. $\mathrm{Bu}$ anlamda turizm, şehirlerin kendilerine kimlik oluşturması adına yapılan çalışmalarda başrol oynamaktadır. Buna göre, bölgesel alanlarda yapılan turizm çalışmaları, pazar arayışında olan sektörlere de yardımcı olmakta ve bu şehirler turizm cazibesiyle birlikte olumlu imaj oluşturarak birer marka şehir olabilmektedir.

Cittaslow Birliği'ne üye olabilmek için belirlenen kriterler ve buraya kadar yapılan açıklamalar çerçevesinde, bu akımın sağlayabileceği katkıların bazıları şu şekilde sıralanabilir:

$\diamond$ Yavaş Şehir Akımı şehirler için önemli bir kalite projesidir. Yavaş Şehir Hareketi, modern yaşam ile geleneksel yaşam arasında köprüler kurarak daha kaliteli yaşam elde etmek için çalışmalar yapmaktadır.

$\diamond$ Yavaş Şehirler insanların sağlıklı yaşaması için oldukça önemli adımlar atmaktadır. Kentler, kendilerine has kaynaklarını ön plana çıkararak organik, yani daha sağlıklı ürünlerin üretimini ve tüketimini teşvik etmektedir.

$\diamond \mathrm{Bu}$ akım kapsamında yer alan kentler, hazır gıda kullanımını azaltacak önlemler almaktadır. 
$\diamond$ Son yıllarda yaygınlaşmaya başlayan Yavaş Şehir Hareketi, kentlerin ulusal kimliğine sahip çıkması için önemli çalışmalar yapmaktadır. Bu şekilde şehirlerin aynılaşmasının da önüne geçilmektedir.

$\diamond$ Yavaş Şehirlerde kadın istihdamı en önemli konulardan biridir. Bu amaca yönelik yapılan çalışmalarla ve verilen eğitimlerle kadınların ekonomik ve sosyal alandaki varlıklarının artırılması amaçlanmaktadır.

$\diamond$ Kent insanının yaşam kalitesi, yiyecek kültürü göz önünde bulundurularak artırılmak istenmektedir.

$\diamond$ Yavaş Şehir Akımı'nın temel felsefesi insan odaklıdır. Daha yaşanılabilir bir dünya ve yenilenebilir enerji kullanımının etkisiyle yok oluşun önüne geçmek amaçlanmaktadır. Cittaslow Birliği'ne üye olan kentlerde çevreye ve insana zararlı olmayan, temiz ve yenilenebilir enerji kaynaklarının kullanımı teşvik edilmektedir. Buna göre kaynakların kullanımı ve tüketimi yavaşlatılarak, sürdürülebilirliğin artırılması amaçlanmaktadır.

$\diamond$ Cittaslow Hareketi'yle beraber yerel kimlik canlandırılarak şehir pazarlama politikalarının kalitesi ve verimliliğinin artırılması amaçlanmaktadır.

$\diamond$ Yavaş Yemek Hareketi kent halkı için bir anahtardır. Yavaş Yemek Hareketi'yle beraber kentler kendi kültürlerini daha rahat pazarlama imkânı bulmaktadır. $\mathrm{Bu}$ anlamda Yavaş Şehir Akımı önemli bir firsat olup, yerel ürünlerin pazarlamasındaki kolaylık bölge kalkınmasına da önemli katkı sağlayacaktır.

$\diamond$ Son dönemde stres önemli sağlık sorunları arasındaki yerini almıştır. Her geçen gün insanlar hayattan zevk alamadıklarını daha fazla vurgulamaktadır. Hayatın giderek anlamsız olması ve aynılaşması insanların psikolojilerini olumsuz etkilemektedir. Buna göre Yavaş Şehir Akımı bu aynılaşmayı ortadan kaldırmak için de bir firsattır.

$\diamond$ Var olan çevrenin korunması, ağaç dikimi ve yeşil alanların korunarak artırılması, bisiklet ve yaya yolları sayısının artırılması, alternatif enerji kaynaklarının kullanılması ve çevreye dost mimari bu akım kapsamında geliştirilebilecek kavramlardır.

Yavaş Şehir Hareketi'nin bu olumlu yönlerinin yanında bu harekete yönelik bazı eleştiriler de vardır. Bu eleştirilerin bazıları şunlardır:

$\diamond$ Yavaş Şehir Akımı'na yapılan en önemli eleştiri; zayıflatılmış, geriye dönük ve tek kalmış toplumlara kolaylıkla yol açabileceğidir (Sezgin ve Ünüvar, 2011: 177178).

$\diamond$ Sakin Şehirlerde yaşayan halk genel olarak bu süreçten memnun görünmektedir. Ancak ilerleyen dönemde, nüfus artışının da etkisiyle Sakin Şehir özelliğinin kaybedilmesinden endişe duyulmaktadır. Buna göre; Sakin Şehir 
Hareketi’yle bağdaşmasa da, özellikle imar alanlarıyla ilgili istenmeyen haberler ve tüketim çılgınlığının körüklenmesi önemli bir sorun olabilir.

$\diamond$ Yavaş Şehir sakinlerinin bir diğer korkusu, bu akımın etkisiyle beraber şehirde betonarme yapılaşmanın artarak devam etmesidir. Akımın etkisiyle beraber üye olan şehirlerde birçok proje hayata geçirilmektedir. Her geçen gün yükselen binalardan halk endişelenmektedir.

$\diamond$ Mimari alanda yaşanan canlılıkla beraber yeşil alanlara da zarar verilebilir.

$\diamond$ Her geçen gün büyüyen ve şehirlerin markalaşmasına yardımcı olan bu hareketin özel çıkarlara hizmet etmesi ve rant sağlamak için bir araç olmasından da endişe edilmektedir.

Görüldüğü gibi Sakin Şehir Hareketi'ne yönelik olumsuz eleştiriler olsa da, olumlu yönler ağırlıklı olarak öne çıkmaktadır. Bu değerlendirmeler 1şığında, Türkiye'nin ilk Sakin Şehri olan Seferihisar aşağıda incelenmektedir. Bu incelemeyle Sakin Şehir olmanın bir șehre sağladıkları ve sağlayabilecekleri hem Seferihisar özelinde, hem de Türkiye'ye yönelik yeni potansiyel Sakin Şehir adayları genelinde ortaya konulmaya çalışılacaktır.

\section{Yavaş Şehir Örneği Olarak Seferihisar}

\subsection{Genel Olarak Seferihisar}

Türkiye'nin ilk Sakin Şehri olan Seferihisar, İzmir il merkezine 45 km uzaklıkta olup önemli turizm merkezlerinden biridir. Sakin Şehir olmadan önce 2008 y1lı verilerine göre Seferihisar'ın nüfusu 23.699 idi. Sakin Şehir olunduğu 2009 yılında nüfus önce 25.308 'e ve 2010 y1lında da 29.232'ye yükselmiştir. Bu verilere göre, Türkiye'nin ilk Sakin Şehri olarak dikkatleri üzerine çeken Seferihisar, 2010 yılında en çok göç alan ilçe olmuştur (haberler.com, 2011). Buna göre, 2010 yılında ilçenin nüfusu 29 bin 232'ye ulaşmıştır. Seferihisar'ın nüfusu 2016 yılı “Adrese Dayalı Nüfus Kayıt Sistemi’ne göre 37.697 kişi olarak belirlenmiştir (nufusu.com, 2017).

Seferihisar'ın tarihi, Teos antik şehriyle birlikte 3000 yıl gerilere gitmektedir. Özenle korunan yerel lezzetleriyle Seferihisar ziyaretçilere farklı tatlar sunmaktadır. Seferihisar'da biri organik olmak üzere her hafta dört pazar kurulmakta olup, her yıl düzenlenen Tohum Takas Şenliği'nde yerli tohumlar yaygınlaştırılmakta ve çoğaltılarak çiftçilere dağıtılmaktadır (Atlas, 2015: 8-9)

Seferihisar 2009 yılında Cittaslow Hareketi'ne katılmıştır. Seferihisar küreselleşmenin kentleri aynılaştırmasına ve özelliklerini yok etmesine karşı çıkan birliğin belirlediği kriterleri yerine getirerek Türkiye'nin ilk Cittaslow'u olmuştur. Belediyenin yavaş felsefesini benimsemesi ve gerçekleştirdiği projeler Seferihisar'1 bu alanda örnek bir belediye haline getirmiştir. Peyzajda yöresel hoş kokulu bitkilerin kullanılması, güneş enerjili sokak aydınlatma araçları, karbon salınımının hesaplanması, kompost tesisi ve güneş enerji santrali yapımı gibi 
projeler Seferihisar'in vizyoner projeleri arasında yer almaktadır (Cittaslow Türkiye, 2015).

\subsection{Seferihisar'ın Ekonomik ve Mali Yapısı}

TÜİK verilerine göre, Seferihisar'ın 2000'li yıllardaki GSYH'si yaklaşık 6.6 milyon TL olup, ilçe bu tutar ile il genelinde 24. sırada yer almaktadır. İlçe 2.693\$ kişi başı gelir ile de il genelinde 21. sırada yer almaktadır. İlçede hidroelektrik, jeotermal, rüzgâr ya da doğalgaz santrali bulunmamaktadır. Seferihisar'da SGK'na bağlı çalışan sayısı 2.211 kişi ve yine SGK'na bağlı emekli sayısı 1.071 kişidir. Seferihisar'da 12 adet yabancı sermayeli şirket faaliyetini sürdürmektedir. İlçede 1997-2007 yılları arasında teşvik belgeli yaklaşık 4.729.730\$ tutarında 1 yabancı sermayeli yatırım gerçekleşmiştir. Yapılan yatırımın konusu, tarım, avcılık ve ormanciliktır (İTO, 2015: 850).

İlçenin sanayi ve ticaret hayatında çeşitli alanlarda faaliyet gösteren işletme, fabrika, atölye ve imalathaneleri bulunmaktadır. İlçe merkezinde tanzim et satış mağazası ve otobüs işletmesi olmak üzere 2 adet belediye iktisadi teşekkülü, 11 adet un fabrikası, 9 adet mandıra, 8 adet zeytinyağı fabrikası, 11 adet yaş meyvesebze paketleme işletmesi, 2 adet beşer tonluk süt toplama merkezi, 50 adet marangoz imalathanesi, 10 adet soğuk demir atölyesi, 6 adet alüminyum ve 4 adet plastik imalathanesi bulunmaktadır (Şahinkaya, 2010: 12).

2006 yılı verilerine göre Seferihisar'da; Gelir Vergisi mükellef sayısı 554, Kurumlar Vergisi mükellef sayısı 290, Katma Değer Vergisi mükellef sayısı 1.068 ve diğer vergi mükellef sayısı da 7.054 adet idi (ITTO, 2015:864).

Yavaş Şehir Akımı'yla beraber şehirdeki iş olanaklarının artması mükellef sayılarına da yansımıştır. Buna göre, Yavaş Şehir Akımı'nın büyümesi, şehirlerin ekonomilerinin büyümesinin de habercisi olabilmektedir. Tablo 1'de görüldüğü gibi Seferihisar'daki hemen hemen tüm mükellef sayılarında artış yaşanmıştır.

Tablo 1: Seferihisar Mükellef Sayıları, 2014

\begin{tabular}{|l|r|r|r|r|r|}
\hline & 31.12 .2010 & 31.12 .2011 & 31.12 .2012 & 31.12 .2013 & 31.12 .2014 \\
\hline Faal Mükellef & 2.143 & 2.287 & 2.543 & 2.819 & 2.916 \\
\hline Gelir Vergisi & 881 & 910 & 956 & 995 & 1.035 \\
\hline Kurumlar Vergisi & 275 & 275 & 263 & 260 & 276 \\
\hline KDV & 1.109 & 1.143 & 1.186 & 1.219 & 1.280 \\
\hline Gelir Stopaj & 1.200 & 1.234 & 1.276 & 1.311 & 1.369 \\
\hline GMSI & 417 & 525 & 708 & 917 & 947 \\
\hline Basit Usul & 480 & 485 & 503 & 517 & 534 \\
\hline Gelir Geçici & 859 & 893 & 928 & 961 & 1.004 \\
\hline Kurum Geçici & 250 & 246 & 244 & 241 & 262 \\
\hline
\end{tabular}

Kaynak: GİB (2014), "Seferihisar Mükellef Sayıları”, http://www.gib.gov.tr

Tablo 1'de görülen mükellef sayılarındaki bu artış, Yavaş Şehir Akımı'nın Seferihisar'a ekonomik ve mali açıdan katkı sağladığının önemli kanıtlarından biri olarak kabul edilebilir. Seferihisar'n Cittaslow olduğu yıl ile 5 yıl sonrası 
karşılaştırıldığında bu katkı daha net ortaya çıkmaktadır. Buna göre, Seferihisar'da 2010 yılı verilerine göre 2.143 olan faal mükellef sayısı, 2014 yılı sonu itibariyle 2.916'ya yükselmiştir. Gelir Vergisi mükellef sayılarında da sürekli olarak artış yaşanmıştır. 2010 yılında 881 olan Gelir Vergisi mükellef sayısı 2014 yılı sonunda 1.035 olmuştur. 2013 ve 2014 yılları karşılaştırıldığında Seferihisar' daki Gelir Vergisi mükellef sayısında \%4'lük bir artış yaşanmıştır. Söz konusu dönemde Türkiye genelinde Gelir Vergisi mükellef sayısında yaşanan artış ise yalnızca \%0,04 olmuştur (GİB, 2014). Bu karşılaştırma üzerinden Cittaslow'un etkisiyle Seferihisar'da ekonomik anlamda bir canlılık yaşandığı söylenebilir.

Kurumlar Vergisinde yaşanan gelişmeler incelendiğinde de benzer bir sonuca varılabilir. Buna göre, Seferihisar'da 2014 yılında Kurumlar Vergisi mükellef sayısı 276 kişi olmuştur. Bu sayı, bir önceki yıla oranla \%6'lık bir artış anlamına gelmektedir. Buna karşın Türkiye genelinde söz konusu dönemde Kurumlar Vergisi mükellef sayısında yalnızca \%2'lik bir artış yaşanmıştır (GİB, 2014).

\subsection{Seferihisar'da Tarım}

İlçe ekonomisi önemli ölçüde tarıma ve özellikle Satsuma mandalina, sebzecilik ve zeytinciliğe dayalıdır. İlçede son yıllarda süs bitkileri ağırlıklı olmak üzere seracılık faaliyeti ve şaraba yönelik üzüm üretimi artmakta olup, halkın \%80'i tarımla uğraşmaktadır (İTO, 2015: 852).

Çiftçi sayısının artması Seferihisar pazarına da yansımıştır. Yavaş Şehir Hareketi'nin etkisiyle de ilçede 30 civarında olan tezgâh sayısı 300'ü aşmıştır. Yavaş Şehir üyeliğinden sonra Seferihisar'da çeşitli çalışmalar yapılmıştır. Buna göre, ilçede üretici pazarları kurulmuş ve yerli tohumlara sahip çıkılmıştır. Bu amaca yönelik olarak ilçede 2011 yılında Tohum Merkezi kurulmuş ve her yıl “Tohum Takas Şenliği” düzenlenmeye başlanmıştır (C. Balta, Kişisel Görüşme, 2015).

Seferihisar'da Cittaslow üyeliğinden sonraki süreçte, organik tarım alanında çeşitli çalışmalar yapılmıştır. 2008 yılında İzmir Büyükşehir Belediyesi'nin başlattığı projede, Orhanlı Köyü pilot bölge olarak seçilmiştir. Seferihisar'da 2015 yılı itibariyle organik tarım faaliyeti gösteren tesis sayısı 4 'tür. Seferihisar Gıda, Tarım ve Hayvancılık İlçe Müdürlüğü'nün katkılarıyla bölgede organik tarım ve iyi tarım uygulamaları yaygınlaşmaktadır. 2015 yılı verilerine göre, 250 ailenin sertifikalı olarak organik tarım yaptığı Seferihisar'da 140 aile de iyi tarım uygulaması ile üretim gerçekleştirilmektedir (seferihisar.com, 2015).

\subsection{Seferihisar'da Sanayi}

Cittaslow şehirlerinin genel özelliğiyle tutarlı şekilde Seferihisar'da da sanayi sektörü gelişmemiştir. İlçedeki tesisler, şehrin ihtiyaçlarını karşılamaya yönelik küçük işletmeler şeklindedir. Şehirde ilçenin adıyla özdeşleşen ürünü olan Satsuma mandalinayı paketlemek için 13 adet narenciye paketleme tesisi, 13 adet zeytinyağı fabrikası, 7 adet mandıra ve 1 adet ambalaj fabrikası bulunmaktadır. 
Organize Sanayi Bölgesi ve Serbest Bölgesi olmayan İlçede 1 adet küçük sanayi sitesi vardır. Küçük işletmelerin bulunduğu sanayi sitesi 1987 yılında kurulmuştur. $15.000 \mathrm{~km}^{2}$ 'lik alan üzerinde faaliyet gösteren sitede 180 işletme vardir (İTO, 2015: 860).

\subsection{Seferihisar'da Turizm}

Turizm sektörü, İzmir'in diğer kıyı ilçelerinde olduğu gibi, Seferihisar'da da belirli düzeyde gelişim göstermiştir. Seferihisar İzmir Adnan Menderes Havaalanı'na 40 km, kent merkezine ise 45 km uzaklıktadır. İlçenin İzmir'e yakın oluşu, düzenli ve sık ulaşım imkânı özellikle yaz aylarında denize girme amaçlı günübirlik ziyaretleri yoğunlaştırmaktadır. Seferihisar'da turizm, iç turizm ağırlıklıdır. Ancak konaklamalı iç turizm, yabancı konaklamalarına oranla oldukça düşüktür. Dış turizm ise, ilçe kıyılarındaki tesislerin tur bağlantıları kapsamında yürütülmektedir.

Seferihisar ilçesi kıyılarında birçok yerde (Sığacık, Doğanbey-Payamlı, Ürkmez) kıyı turizmi (deniz turizmi) gelişmiştir. İlçede; $60 \mathrm{~km}$ 'lik sahil şeridi ve birbirinden güzel koylar ile plajlar bulunmaktadır. Bunlardan en önemlileri; Azmak, Küçük Akkum, Büyük Akkum, Ekmeksiz, Bahadır, Çıfıt Kalesi, Doğanbey Payamlı, İpekkum ve Ürkmez'dir (İTO, 2015: 861).

Seferihisar'da Sakin Şehir olunduktan sonra, turizm daha da önemli hale gelmiş ve turizmin ilçe ekonomisine katkısı artmıştır. Bu amaca yönelik olarak turizm alanında yapılan yatırımlar da ön plana çıkmıştır.

Seferihisar Cittaslow olduğu dönemde hiç mavi bayraklı plaja sahip değildi. Yavaş Şehir Akımı'nın etkisiyle de bu alanda çalışmalar yapılmış ve şehir 2014 yılında 5 tane mavi bayraklı plaja sahip olmuştur (KTB, 2015). Seferihisar'da 2016 yılında mavi bayraklı plaj sayısı 13'e yükselmiş ve bu sayı ile İzmir'de en yüksek rakama ulaşılan ilçe olunmuştur. Aynı şekilde Seferihisar oluşturulan 10 "Belediye Halk Plajı" sayısı ile Türkiye genelinde birinci olmuştur (seferihisar.bel.tr, 2016).

Seferihisar Yavaş Şehir olduktan sonra şehirde turizme yönelik çeşitli çalışmalar yapılmıştır. Yapılan çalışmalar şunlardır (Şahinkaya, 2010: 16):

$\diamond$ Çocukların doğal üretimi öğrenmeleri amacıyla bahçeler oluşturulmaktadır.

$\diamond$ Yerel üretimin desteklenmesi için ticari merkezler kurulmasına yönelik kriteri karşılamak amacıyla "Köy Pazarı" kurulmuştur. Eski belediye binası Seferihisar'ın 8 köyüne tahsis edilmiştir. Burada köylüler, kendi ürünlerini sunma imkânı bulmaktadır. Şehirde haftanın bir günü de açık pazar kurulmaktadır.

$\diamond$ Seferihisar'da bisiklet yollarının yapımı projesi sürdürülmektedir. Bu konuda Belediye Başkanı Tunç Soyer şunları söylemiştir: "Güneş enerjisi ile çalışan bir bisiklet ürettik. İlçe, rampaları pedal çevirmeden çıkmaya olanak sağlayan bisiklete sahip olacak". 
Belirli saatlerde kent merkezine motorlu araç alınmayan Seferihisar'da fayton uygulamasını başlatmak için girişimler sürdürülmektedir.

$\diamond$ Görüntü kirliliği bulunan ana cadde tamamen yenilenmektedir. Bütün tabelalar değiştirilmektedir.

$\diamond 20$ ressamla sürdürülen çalışmalar neticesinde, evlerin cephelerinin boyanması, kolonların taş kaplanması, klimalara ahşap ızgara yapılması ile pencere ve balkonlara sardunya konulmasına karar verilmiş ve bu amaçla 4 bin sardunya fidelenmiştir.

$\diamond$ Seferihisar'da 75 yaş üstü yurttaşlar bir araya getirilerek yaşlıların anlattıkları anıların derlenmesinden oluşacak Seferihisar Sözlü Tarihi kitabı çıkartmak hedeflenmiştir.

$\diamond$ Yılın 300 gününü güneşli geçiren Seferihisar aynı zamanda zengin termal enerji kaynaklarına ve güçlü rüzgâr koridorlarına sahiptir. Bu çerçevede öncelikle kentin 1sınmasında jeotermal enerjiyi kullanma hedeflenmektedir. Ayrica kentin aydınlatılmasında güneş ve rüzgâr enerjisi kullanan yeni estetik aydınlatma elemanları projelendirilmiş durumdadır.

$\diamond$ Yerel yemek lokantalarının oluşturulmasına hız verilmiştir. Bu konuda esnaf eğitimine de İzmir'deki üniversitelerden alınan desteklerle devam edilmektedir.

$\diamond$ Turizm konusunda her şey dahil sistemi yerine ev pansiyonculuğu ve çevreye saygılı, doğal ve tarihi mimari dokuya uygun butik otellerin öne çıkacağı bir projenin olgunlaştırılmasına gayret gösterilmektedir. Bu çerçevede eko-turizmin yaygınlaştırılması amacıyla kentin tamamının turistik bir merkez haline getirilmesi hedeflenmiş durumdadır.

Seferihisar, Yavaş Şehir üyeliğinden sonra dünya çapında bilinen bir şehir haline gelmiştir. Yavaş Şehir Akımı'yla beraber yapılan çalışmaların, şehrin tanıtımına çok önemli katkısı olmuştur. En önemli katkıyı ise 2013 yılında Yavaş Şehirler Genel Kurulu'nun Seferihisar'daki toplantısı sağlamıştır (ETİK, 2013: 53).

Bilindiği gibi Kültür ve Turizm Bakanlığı "Türkiye Turizm-2023 Stratejisi" kapsamında; turizm sektöründe, kamu ve özel sektörün yönetişim ilkesi çerçevesinde işbirliğini gündeme taşıyan ve stratejik planlama çalışmalarının yönetim ve uygulamasına yönelik açılımlar sağlamasını hedefleyen bir çalışma yapmıştır. Katılımcı planlama anlayışı ile hazırlanan Türkiye Turizm-2023 Stratejisi kapsamında çeşitli hedefler belirlenmiştir. Bu hedefler genel olarak şu şekildedir (KTB, 2007: 1-10):

$\diamond$ Fiziki planlama uygulanması ile ilgili eksiklikler, çeşitli yasal koordinasyon düzenlemeleri ile birlikte ortadan kaldırılacaktır.

$\diamond$ Yerel düzeyde turizm potansiyeli bulunan alanlarda sorun odaklı planlama anlayışı yerine, planlama çalışmaları bütüncül olarak ele alınacaktır. 
$\diamond$ Parçacı ve parsel bazında gelişen planlama pratiği sona erdirilerek dünya çapında yarışabilir turizm kentleri oluşturulacaktır.

$\diamond$ Yerel düzeyde plan onama yetkisine sahip kurum ve kuruluşlara teknik personel desteği sağlanacak, böylece yerel bazda turizm gelişimi yönlendirilecektir.

$\diamond$ Yerel ölçekte nokta bazında Konseylerin işler kılınması ile "Yerel Gündem 21" gibi katılımcı mekanizmaların oluşturulması sağlanacaktır. Yerel ölçekte turizm gelişim bölgelerinin seçiminde organize turizm faaliyetlerinin geliştirilebileceği geniş alanlar tercih edilecek, mülkiyet, altyapı ve çevre gibi konular için de çözüm önerileri ve sistemli bir yapılanma sağlanacaktır.

$\diamond$ Turizmin geliştirilmesine yönelik bir takım tedbirler alınarak sektörün genel olarak ekonomiye katkı sağlaması açısından bazı teşvikler sunulacaktır.

$\diamond$ Küçük ve Orta Büyüklükte İşletme (KOBİ) tanımına giren turizm konaklama tesislerinin yanı sira seyahat acentelerinin de bu destekten yararlandırılmalarını sağlayacak vergi rejiminde düzenlemeler yapılacaktır.

$\diamond$ Turizm sektöründe yabancı sermayenin ülkemize yatırım yapması sağlanacaktır.

$\diamond$ Turizm yatırımlarının teşviki süreci kapsamında tanıtım ve pazarlama politikaları geliştirilecektir.

$\diamond$ Turizmin çeşitlendirilmesi için tüm yıla ve yurda yayılmasına imkân veren projeler geliştirilerek kıyıların dışındaki bölgelere de yatırım yapılması teşvik edilecektir.

Yukarıda belirtilen hedefler göz önüne alındığında Türkiye Turizm Stratejisi2023, Cittaslow uygulaması için bir firsata dönüştürülebilir. Buna göre, Strateji2023 hedefleri çerçevesinde yapılacak olan uygulamalar büyük ölçüde Yavaş Şehir Akımı ile kesişmektedir. Örneğin; turizm yatırımlarının tanıtımının artırılması için Yavaş Şehir önemli bir fursattır. Türkiye'de bilinirliği az olan birçok şehir, bu akım sayesinde hem yurtiçinde hem de yurtdışında adını duyuracaktır. Seferihisar bu markalaşma yolculuğunun en güzel örneğidir. Buna göre, yukarıda belirtilen hedefler çerçevesinde ve Yavaş Şehir Akımı ile şehirlere yapılan yatırımlar da artarak devam edecektir.

Bilindiği gibi şehir turizmi, anakent ölçeğindeki büyük şehirlerde gerçekleştirilen bir turizm türüdür. Paris, Londra, Montreal ve Prag şehir turizminin yapıldığı en önemli kentler arasındadır. Şehir turizminde şehrin turizm potansiyeli ve çizdiği imaj çok önemlidir. Bu nedenle, şehrin tüm çekim noktalarının maksimum düzeyde kullanılması gerekmektedir. Ülkemizde öncü örnek olarak dünyanın en büyük turizm potansiyeline sahip metropollerinden biri olan İstanbul'da ve diğer büyük şehirlerden Ankara, İzmir ve Antalya'da şehir turizmi projesi başlatılması önerilmektedir. 2010 y1lında Avrupa Kültür Başkenti olarak İstanbul'un 
belirlenmesi bu şehrimizin kültür, sanat, şehircilik ve çevresel kalite olarak güçlendirilmesini gündeme getirmiştir (Şahinkaya, 2010: 17-18). Yavaş Şehir Hareketi'yle beraber bu harekete üye ilçeler de birer marka şehir haline getirilerek turizm pastasından pay almaya başlayabileceklerdir. Yavaş Şehir ilçeleri büyük bir turizm odağı haline gelmeseler de, bu akım sayesinde yerel kalkınma alanında önemli adımlar atılabilecektir.

\subsection{Seferihisar'ın Ticaret ve Yatırım Profili}

Pazar konusunda çok geniş kitlelere ulaşan Seferihisar internet aracılığıyla da pazarlama faaliyetlerini gerçekleştirmektedir. Buna göre, internet adresi aracılığıyla e-satış kapsamında organik pazarda sergilenen ürünlerin satış1 yapılmaktadır (seferipazar.com, 2017).

Seferihisar'da, Belediye ve Buğday Derneği işbirliği ile açılmış olan \%100 doğal ekolojik pazar, cumartesi günleri halka hizmet vermektedir. Seferihisar'daki bu pazar, Türkiye'nin en çevreci, en sosyal-kültürel, en yerel ve en ucuz pazarı olmayı hedeflemektedir. Gerçekleşmiş bu proje sadece organik tarıma değil yerel ekonomilere ve küçük ölçekli üreticilere de öncelik veren bir proje olmayı hedeflemektedir (Prezi, 2013).

Seferihisar'daki yatırım profili, kamu yatırımları ve özel yatırımlar olmak üzere iki başlık altında incelenebilir. Kamu yatırımları; Seferihisar Belediyesi yatırımları, Sağlık Bakanlığı yatırımları, Sanayi ve Ticaret Bakanlığı yatırımları ve İzmir Büyükşehir Belediyesi yatırımlarından oluşmaktadır. Kamu yatırımlarında bazı projelerde İzmir Kalkınma Ajansı (IZKA)'nın desteği alınmaktadır. Buna göre Seferihisar'da; tarım ve balıkçılık, turizm, kadın girişimciliği, ulaşım, altyapı, sinema, spor, yenilebilir enerji ve gayrimenkul gibi alanlarda gerçekleştirilen veya hedeflenen çok sayıda kamusal veya özel proje olduğu görülmektedir (Prezi, 2013).

Seferihisar'da gerçekleştirilen projeler arasında Seferihisar Belediyesi'nin öncülüğünde ilçeye özgü dünyanın en kaliteli mandalinası olarak gösterilen Satsuma'nın jeotermal enerjide kurutulmasını özellikle vurgulamak gerekir. Buna göre, yapılan deneme üretimlerinden sonra 350 tona çıkarılan kurutma işlemi kapasitesiyle önemli bir ihraç ürünü geliştirilmiştir (seferihisar.com, 2017).

\subsection{Seferihisar'da Kadın İstihdamı}

Yavaş Şehir Hareketi'nin olumlu etkilerinden biri de kadın istihdamını artırmasıdır. Bu anlamda Seferihisar örneğinde de kadınların daha fazla üreten konuma gelmiş olduğu söylenebilir. Bu durum, Seferihisar ilçesi ziyaret edildiğinde çılak gözle bile fark edilebilmektedir. Buna göre, Seferihisar'da kadınlar özellikle organik tarım, pansiyonculuk ve yöresel yemek sunumu gibi konularda ön plandadır.

Seferihisar'da Belediye'nin katkılarıyla Kadın Emeği Evleri açılmıştır. Bu evler sayesinde kadınlar harcadığı emeğin karşılığını almakta, çeşitli alanlarda 
kendilerini geliştirmekte ve gelir getiren çeşitli faaliyetlerde çalışmaktadır (Sungur, 2013: 645). Kadın Emeği Evleri'nin ilki 8 Mart 2010 tarihinde Ulamış Mahallesinde, ikincisi 17 Haziran 2010 tarihinde Atatürk Mahallesi Doğanbey Eski Köy'de açılmıştır (Cittaslow Türkiye, 2015).

Türkiye'de 1950 sonrası dönemde eğilim, milli gelirde ve istihdamda tarım sektörünün payının azalmasına koşut olarak kadınların iş gücüne ve istihdama katılım oranlarının gerilemesi yönündedir. Bu anlamda, Yavaş Şehir Hareketi'nin kadın girişimciliğinin artmasında etkili olması ve gerçekleştirilen çalışmalar diğer kadınlara da örnek teşkil etmektedir. Kadınlar aldıkları girişimcilik eğitimi doğrultusunda yaptığ 1 çalışmalar sonucu bir araya gelerek kooperatifler kurmaktadır (Sungur, 2013: 647).

Bilindiği gibi, Türkiye'de kadınların çalışma hayatına katılımları, diğer ülkelerle kıyaslandığında çok geride kalmıştır. Şekil 1'de görüldüğü gibi, 2013 yılı verilerine göre, Avrupa Birliği ülkelerinde kadınların işgücüne katılım oranı \%62,5 iken, bu oran Türkiye'de yalnızca \%31,8'dir (TÜRKONFED, 2014).

Şekil 1: Kadınların İşgücüne Katılım Oranları (2013)

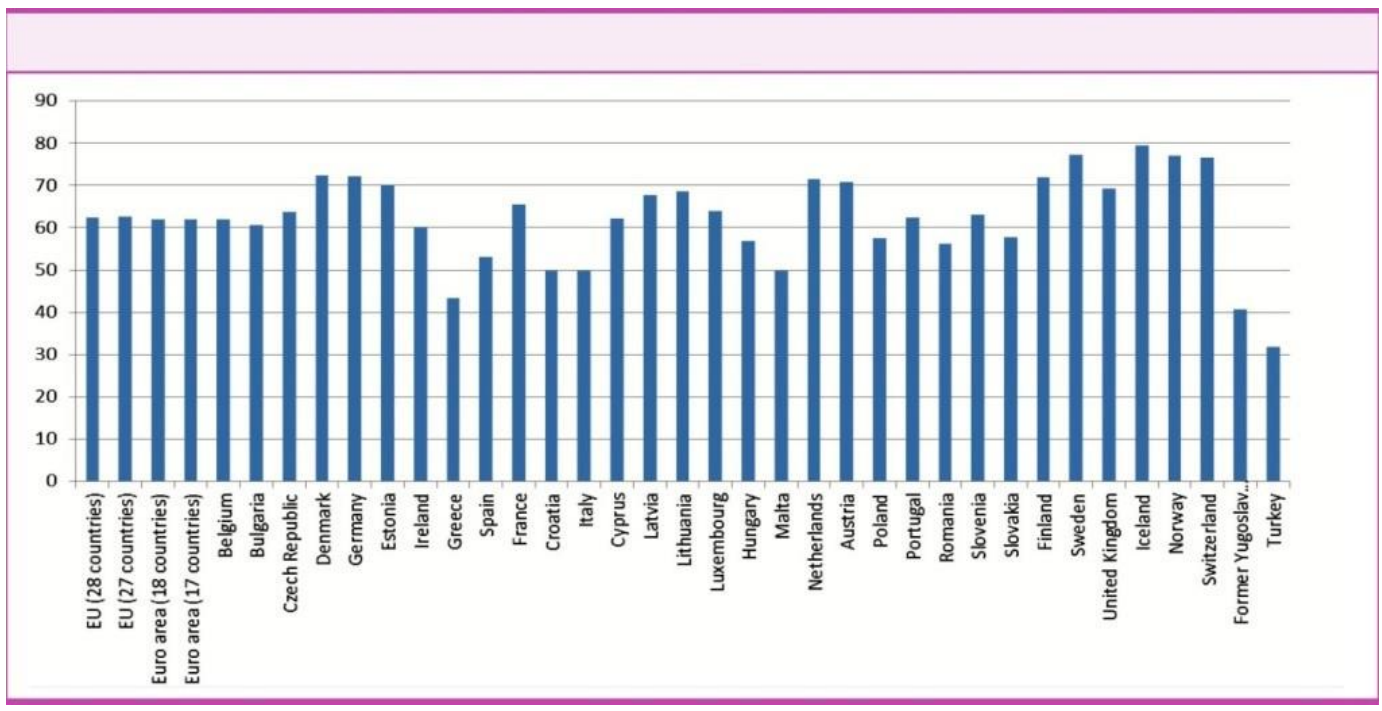

Kaynak: TÜRKONFED, 2014.

TÜİK verilerine bakıldığında da, Türkiye'de 2015 yılı Ocak dönemi itibariyle işgücüne katılma oranı $\% 50$ olarak gerçekleşirken, bu oranın erkeklerde $\% 70,5$, kadınlarda ise yalnızca \%29,9 olduğu görülmektedir (TÜİK, 2015-1).

İstatistiklere göre Türkiye'de nüfusun yarısını oluşturan kadınların istihdam oranının, erkeklerin istihdam oranının yarısı kadar bile olmadığı görülmektedir. Bu durumu düzeltmek için Yavaş Şehir Akımı'ndan yararlanılabilir. Buna göre, bu akım bir fırsat olarak değerlendirilip, Seferihisar özelinde görüldüğü gibi, Türkiye'de kadınların işgücüne katılım oranının arttırılması sağlanabilir. 
Şekil 2: Kadın-Erkek İşsizlik Oranı, 2004 - 2014

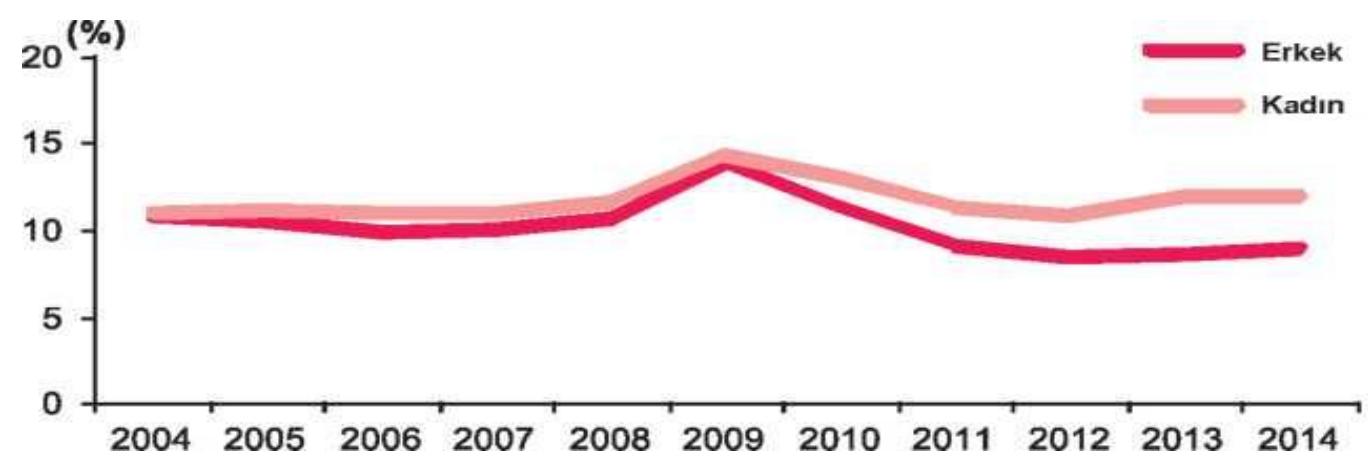

Kaynak: TÜIK, 2015-2: 82

Şekil 2'ye bakıldığında; yıllara göre işsizlik oranları itibariyle kadınlarda işsizlik oranı, erkeklerden daha fazladır. Bu durum yıllar içinde azalmak yerine 2000'li yılların başında \%11 iken, 2013 yılında \%12'lere kadar yükselmiştir. Yavaş Şehir Hareketi'yle meslek sahibi olan kadınlar düşünüldügünde ve buradaki verilere bakıldığında; bu uygulamanın ülke genelinde yaygınlaştırılmasıyla işsizlik oranında kadınlar açısından bir azalmanın olması ve ekonominin bundan olumlu etkilenmesi beklenebilir. Gerçekleşecek çalışmalarla birçok yeni iş olanağ doğabilir ve yeni kadın istihdamları sağlanabilir. Yeni iş alanları bulan kadınlar, kendilerinin ekonomiye doğrudan katkısı yanında çalıştırdığı işçilerle de ekonomik katkı sağlayabilirler. Örneğin; bizzat yapılan ziyaretler çerçevesinde, Seferihisar'da organik pazarların kurulmasıyla beraber kadın pazarcıların sayısının arttığı ve kadın pazarcıların yanlarında eleman çalıştırmaya başladıkları da gözlemlenmiştir.

Türkiye'de kentsel nüfusun artmasına rağmen kadın istihdamının yine de artmıyor olması, Seferihisar örneğindeki gibi Sakin Şehir uygulamalarının önemini artırmaktadır. 2013 verilerine göre, Türkiye'de istihdam edilen kadınların \%39,2'si tarımda, \%45'i hizmetler sektöründe, \%14,8'i de sanayi sektöründe çalışmaktadır. Daha çok kentsel istihdamın göstergesi olan sanayi ve hizmetlerdeki oran kentsel nüfusun hızlı artışına rağmen çok yavaş bir gelişim seyri izlemektedir. $\mathrm{Bu}$ durumun kentleşme eğiliminin kentlerdeki kadın istihdamını artırmadığ şeklinde yorumlanmaktadır (ÇSGB, 2013). Bu anlamda Sakin Şehirlerin organik tarım, el sanatları ve konaklama tesisleri gibi uygulamalara katkısı göz önüne alındığında Türkiye'deki kadın istihdamı sorununun çözümüne katkısı olacağı söylenebilir.

Sakin Şehir uygulaması ile Türkiye'de kadınların kayıtdışı istihdamı sorununun çözümüne de katkı verilebilir. Kayıtdışılığın kadının çalışma hayatına katılmasını engellediği söylenebilir. Buna göre, sosyal güvenlikten yoksun olan kadınlar iş dünyasına girmekten kaçınmaktadırlar. Türkiye'deki çalışma hayatında kadınlar erkeklere göre daha fazla kayıtdışı çalışmaktadırlar. TÜİK (2013) verilerine göre, Türkiye'de istihdamın \%36,8'i kayıtdışıdır. Türkiye'de kayıtdışı istihdam oranı, 
erkeklerde \%30,4 iken kadınlarda \%51,6'ya yükselmektedir. Kadınlar için bu oranın yüksek olmasının nedeni ise, kadınların çoğunlukla kayıtdışılığın daha yüksek olduğu, emek yoğun sektörlerde (tekstil, hazır giyim, gıda ve hizmet vb.) istihdam imkânı bulabilmesidir. Sakin Şehir uygulamalarının faaliyet alanları itibariyle kayıtdışılığı engellemesi ve kayıtlı istihdamı teşvik etmesi beklenebilir. $\mathrm{Bu}$ yönüyle Yavaş Şehirler kayıtlı kadın istihdamının artmasına da yardımcı olacaktır.

\subsection{Seferihisar ve Kayıtdışı Ekonomi İlişkisi}

Kayıtdışı ekonomi, kısaca devletten gizlenen ve kayda geçirilmeyen, bu nedenle de denetim dışında kalmaya özen gösteren faaliyetlerin tümü olarak tanımlanabilir. Buna göre, kayıtdışı ekonomi, GSMH hesaplamalarına dahil edilmeyen alanı temsil etmektedir. Devlet otoritesini zarara uğratması ve kamu gelirlerini yok etmesi gibi yönleriyle kayıtdışı ekonominin önemli zararları vardır (Alptürk, 2015).

2016 yılı itibariyle Türkiye'deki kayıtdışı ekonomi verileri 34 OECD ülkesi içinde $\% 28,72$ ile en yüksek düzeydedir (hurriyet.com.tr, 2016). Bu oran \%18,4 olan $\mathrm{AB}$ ortalamasının da oldukça üzerindedir (BİK, 2014).

Sakin Şehir uygulaması kayıtdışı ekonomi sorununun çözümüne katkı verecek güncel bir uygulamadır. Bu akımla beraber özellikle nüfusu yoğun olmayan ve ekonomik açıdan istediği düzeye ulaşamayan şehirler, kalkınmalarını kendi içinde yoğrularak gerçekleştirebilir ve ülke ekonomisine de önemli katkı sağlayabilir. Sakin Şehirlerde yerel halk, şehirlerin kendine özgü yapısı çerçevesinde ve geleneksel olanı devam ettirerek şehirlerini cazibe merkezi haline getirmektedir. Turizm alanında adını duyurmaya başlayan ve markalaşma yolunda ilerleyen bu şehirler, yavaş yavaş beklediği ekonomik sonuçlara ulaşarak mali canlılık yaşamaktadır. Ekonomisi her geçen gün canlanan ve turizm yoğunluğu artan bu şehirlerde kayıtlı iş olanakları açısından da olumlu süreç yaşanmaktadır.

Sakin Şehir-kayıtdışı ekonomi ilişkisi açısından belirtilen bu olumlu özellikler Seferihisar örneğinde gözlemlenmektedir. Seferihisar'da mandalina yetiştiriciliği kentin önemli ekonomik kaynaklarından biridir. Kentte Sakin Şehir üyeliğinin ardından 2011 yılında "Mandalina Üretici Birliği” kurulmuştur. Seferihisar'da her yıl "Turuncu Festival" adı altında mandalina festivali düzenlenmektedir. Bu festivale önemli oranda yerli ve yabancı turist katılmaktadır (C. Balta, Kişisel görüşme, 2015). "En İyi Mandalina Yetiştiricisi", "Mandalina Kral ve Kraliçesi", "En İyi Mandalinalı Yiyecek", "En Yavaş Bisiklet Sürme" ve "En İyi Mandalinalı Hediyelik Eşya Tasarım Yarışması" gibi birçok aktivitenin bulunduğu etkinliğe; İzmir ve çevresinden de büyük katılım olmaktadır (Yeni Asır Gazetesi, 2015).

Çeşitli aktivitelerle renklendirilen festival Seferihisar için aynı zamanda önemli bir gelir kapısıdır. Üreticilerin desteklenmesi ve teşvik edilmesi için her yıl bu festival düzenlenmektedir. Yavaş Şehir Akımı'nın Türkiye'de birçok şehre yayılmasıyla beraber, ülkenin çeşitli şehirlerinde, o şehrin kendine özgü değerleri 
ön plana çıkarılarak şehirlerin kalkınmasında önemli katkı sağlanması beklenebilir. Seferihisar ve mandalina örneğinde olduğu gibi; mandalinanın toplanması ve pazarlanmasında birçok işçi emek harcamaktadır. Bu işlemler üretici birliği, kooperatif veya bir firma kurularak yapıldığında birçok insana kayıtlı iş imkânı sağlanmıș olacaktır. Mandalina öncülügünde çeșitli organik tarım ürünlerinin yer aldığı dükkânlar da açılabilir. Devlet destekli organik pazarlar çoğaltılarak küçük işletmeler hedeflenip mükellef sayısı arttırılabilir. Çalışan insanlar taşeron firma ve küçük ișletmelerle kayıt altına daha rahat alınabilir ve bu işletmelerin denetlenmesi daha kolay olur.

Sakin Şehir-kayıtdışı ekonomi ilişkisi çerçevesinde belirtilen bu olumlu gelişmeler devletin yapacağı düzenlemelerle daha da geliştirilebilir. Buna göre, Sakin Şehir Akımı'nın etkisiyle geçmişte kayıtdışı yapılan pazarlama faaliyetleri küçük işletmeler kurularak kayıt altına alınabilir. Devletin de kurulacak bu küçük işletmelere bazı teşvikler vermesi beklenebilir. Hatta devletin Sakin Şehir uygulamalarına özel teşvikler vermesi daha doğrudur.

Sakin Şehir uygulamalarında özellikle KOBI'ler kullanılarak bir atılım gerçekleștirebilir. Çünkü Türkiye'deki işletmelerin \%99'unu oluşturan KOBİler, toplam istihdamın \%78'ini, toplam katma değerin \%55'ini, toplam satışların $\% 65$ 'ini, toplam yatırımların \%50'sini ve toplam ihracatın \%60'inı gerçekleştirmektedir (BSTB, 2012). KOBİ'lerin Türkiye ekonomisindeki önemli rolünü açıkça ortaya koyan bu veriler göz önüne alındığında, Sakin Şehir-KOBİ ilişkisi geliştirilerek ekonomik açıdan etkili bir akımın ortaya konulabileceği söylenebilir. Çünkü bütün dünya ekonomilerinde olduğu gibi Türkiye'de de KOBİ'ler; daha az yatırımla daha çok kişiye istihdam imkânı veren, teknolojik değişime daha yatkın, ekonomik dalgalanmalardan çok daha az etkilenen ve talep değişiklik ve çeşitliliğine kolay uyum sağlayan kuruluşlardır (Savaşır, 1999: 189).

\subsection{Seferihisar ve Yenilenebilir Enerji}

Amerika Enerji Bilgi Yönetimi'nin 2012 yılında hazırladığı raporda yenilenebilir enerji için şu bilgilere yer verilmektedir: "Yenilenebilir enerji dünyadaki en hılı büyüyen enerji kaynağıdır. 2010 yılında, fosil yakıtların elektrik enerjisi üretimi açısından payı \%3 ila \%4 artarken, yenilenebilir enerji kaynaklarının payı \%10'dan \%15'e yükselmiştir” (EIA, 2012). Bu araştırma yenilenebilir enerjinin gelecek dönemde daha fazla ön plana çıkacağını göstermektedir. Bu yönüyle bakıldığında Sakin Şehir Hareketi'nin de yenilenebilir enerjiye vurgu yapması önemlidir.

Sakin Şehir olarak Seferihisar Belediyesi de yenilenebilir enerji alanında faaliyetlerde bulunmaktadır. Buna göre; Seferihisar Belediyesi'nin Avrupa Birliği Başkanlar Sözleşmesi'ni (Covenant of Mayors) imzalayarak başlattığı "Sürdürülebilir Enerji Eylem Planı" (SEEP) süreci, Seferihisar ilçesinin hazırlamış olduğu bir teknik doküman olmanın ötesinde, bir sürece işaret etmektedir. Sürdürülebilir Enerji ve Eylem Planı Seferihisar'ı küresel ısınmanın 
tehdit ettiği geleceğe taşıyacak bir adımdır. Söz konusu süreç, uzun vadeli ortak bir vizyona ve bu vizyonu yaşama geçirecek kaynaklara ihtiyaç duymaktadır (Seferihisar Belediyesi, 2015: 46).

Yenilenebilir enerji kaynakları, bugün Türkiye'de kurulumu hızla artan rüzgâr enerjisi santrallerinden görülebileceği gibi, ulusal şebekeye bağlanmış büyük ölçekli güç santralleri biçiminde üretim yapabilirler. Benzer bir durum güneş enerjisi santralleri hatta jeotermalden elektrik elde edilen santraller için de geçerlidir. Buna karşılık yenilenebilir enerji kaynaklarının asıl avantajları, dağıtılmış birimler olarak elektriğin tüketildiği yere yakın konumlandırılmaları ve iletim sistemi kayıplarından etkilenmemeleri ile ortaya çıkmaktadır. Özellikle dağıtılmış, modüler fotovoltaik kurulumlar, Seferihisar gibi yüksek 1şınım potansiyeli olan coğrafyalarda, kentsel güç ihtiyaçlarının karşılanmasında önemli katkılar yapabilir (Seferihisar Belediyesi, 2015: 40).

Seferihisar'ın güneş dışındaki yenilenebilir enerji kaynaklarının da doğrudan kent tarafindan kullanılmak üzere değerlendirilmesi mümkündür. Örneğin jeotermal kaynaklar sıcak su ve ısınma ihtiyaçlarının karşılanmasında; küçük ölçekli rüzgâr ve güneş sistemleri de konutlar, işyerleri ve kamu kuruluşlarında güç ihtiyacını karşılamak için kullanılabilir. Bu tür yatırımlar kentin enerji gereksiniminin doğrudan karşılanmasına yaradıkları gibi sera gazı salınımlarının düşürülmesine de hizmet ederler (Seferihisar Belediyesi, 2015: 40).

Yukarıda da belirtildiği gibi, Seferihisar'da Belediye'nin öncülüğünde kurulan üreticiler birliği, 2015 yılındaki deneme üretimlerinden sonra 2016 yılında günde 350 tona çıkarılan kapasiteyle, mandalinayı jeotermal enerji yardımıyla kurutarak yenilebilir enerji ile şehrin en önemli tarımsal ürününü birleştirip önemli bir örnek uygulama gerçekleştirmiştir (seferihisar.com, 2017).

Seferihisar Belediyesi, Yenilenebilir Enerji ve Çevre Teknolojileri Hibe Programı kapsamında IZKA'dan aldığı hibeyle kapalı pazar yeri güç santrali kurulumu projesini 2014 yılında tamamlamıştır. Böylece Belediye doğayla dost, yenilenebilir enerji kaynaklarına verdiği önemi göstermiştir. Yavaş Şehir kriterleri kapsamında yenilenebilir enerji kullanımını sağlamak konusunda IZZKA ile ortak yatırım olarak gerçekleştirilen proje Türkiye'de örnek projeler arasına girmiştir.

Türkiye'de son y1llardaki uygulamalar katı atık sahalarından enerji elde edilebildiğini göstermektedir. Modern katı atık yönetim uygulamaları ile katı atıkların çevresel etkileri azaltılmakta ve üretilen çöp gazından enerji elde edilmektedir. Bölgede düzenli katı atık sahaları İBB tarafından işletilmekte ve Seferihisar katı atıkları bu sahalarda depolanmaktadır. Seferihisar Belediyesi'nin de, katı atıklardan enerji elde etmek adına biyogaz tesisi kurulumu için İBB'ne destek olması ve kurulacak tesislerden üretilen enerji ile şebeke elektriğine olan bağımlılığın azaltılması amaçlanmaktadır (Seferihisar Belediyesi, 2015: 40). 
Seferihisar Belediyesi; iklimlendirme, ısınma ve aydınlanma amacıyla kullanılan elektrik ihtiyacını güneşten karşılamayı ve bu sayede yılda 125.000 TL elektrik tasarrufu sağlamayı amaçlamaktadır (Seferihisar Belediyesi, 2015).

Verilen bu miktarlar ilk bakışta küçükmüş gibi gözükebilir. Ancak bu tür uygulamalar yaygınlaştırılarak önemli meblağlara ulaşılabilir. Türkiye'de Sakin Şehir potansiyeli olan birçok şehrin olması ve bu şehirlerin büyük bir kısmının da yenilenebilir enerji sahalarına sahip olması bu tür uygulamaların önemini artırmaktadır.

Türkiye'deki enerji profili gözden geçirildiğinde yenilenebilir enerji kaynaklarının yeri ve önemi açıç̧a görülmektedir. Ancak Türkiye'de yenilenebilir enerji kaynaklarının kullanımı oldukça düşük düzeylerdedir (\%1 ve altında). Özellikle, güneş ve rüzgâr enerjisinin kullanımı, Türkiye'nin enerji bütçesine ciddi katkılar sağlayabilir. Buna göre, yenilenebilir enerji kaynaklarından doğru ve sağlıklı bir biçimde yararlanılması için gereken strateji, plan ve politikaların önemi giderek artmakta ve önemli boyutlara ulaşmaktadır (Gençoğlu, 2015: 2).

Türkiye, gerek coğrafi konumu, gerekse doğal kaynaklarının zenginliği ile yenilenebilir enerji üretimi ve kullanımı açısından birçok üstünlüğe sahiptir. Bunun yanında enerji ithal eden bir ülke olarak, öz kaynaklarını verimli kullanması da gerekmektedir (Kaya, 2006: 152).

Yenilenebilir enerjinin önem kazanmasında petrol fiyatlarındaki belirsizlik, enerjide dışa bağımlılık, karbon emisyonları ile ilgili çevresel kaygılar kadar; devlet politikaları (yenilenebilir enerji üretiminde vergi indirimi gibi), yenilenebilir enerji sistemlerinin kurulumu için kredi verme ve yenilenebilir enerji sertifikaları için piyasa oluşturma gibi konular da önemlidir (Bowden and Payne, 2010: 400-408).

Türkiye'yi dünyanın en büyük 10 ekonomisinden biri yapma amacı doğrultusunda Enerji ve Tabii Kaynaklar Bakanlığı, enerjide 2023 yılı hedeflerini revize ederken, yenilenebilir enerjinin payının \%30'a yükseltilmesini ve bu doğrultuda rüzgâr, jeotermal ve güneş enerjisinden çok daha fazla yararlanılacağını vurgulamaktadır (Erdal, 2012: 174-175).

Yenilebilir enerjinin gittikçe artan önemi, Türkiye'nin enerji kullanımı açısından mevcut konumu ve geleceğe ilişkin hedefleri bir bütün olarak değerlendirildiğinde Cittaslow Hareketinden de yararlanılarak bu alanda daha hizlı bir atılım yapılabileceği söylenebilir. Buna göre, yenilebilir enerji uygulamalarına Sakin Şehirler kapsamında daha fazla önem verilerek, özellikle büyükşehirlerin uzağında kalmış, mali açıdan sıkıntı yaşayan kentlere canlılık getirilmesi ve ülke ekonomisine de katkı sağlanması mümkün olabilir.

\section{Seferihisar Çerçevesinde Cittaslow Akımı'na Yönelik Değerlendirmeler}

Yukarıda Yavaş Şehir Akımı'na ilişkin genel bilgilerden sonra Seferihisar örneğinde değerlendirmeler yapılmıştır. Buna göre, Seferihisar'la ilgili nüfus, 
ekonomik ve mali yapı, tarım, turizm, kadın istihdamı, kayıtdışı ekonomi ve yenilebilir enerji gibi konulara ilişkin bilgiler verilerek, bu akım çerçevesinde kentte yaşanan ve yaşanabilecek gelişmelere değinilmiştir. Aynı şekilde Seferihisar örneğinde Sakin Șehir uygulamalarının Türkiye geneline yaygınlaştırılmasının gerekliliğine ve yararlarına da vurgu yapılmaya çalışılmıştır. $\mathrm{Bu}$ incelemeden yola çıkarak, Cittaslow uygulamasına, Seferihisar örneğine ve Türkiye'ye yönelik aşağıdaki tespit ve öneriler yapılabilir:

$\diamond$ Cittaslow, henüz çok genç bir akımdır. Ancak zaman ilerledikçe ve farkındalığı arttıkça, bu uygulamanın ilgili şehirlere katkısı da artacaktır. Kısa vadede bu uygulamadan çok fazla bir beklenti içinde olunmaması gerekir. Uzun vadede düşünüldügünde Sakin Şehir süreci iyi yönetilir ve halka iyi anlatılırsa, şehirlerde özellikle turizm başta olmak üzere belirli alanlarda canlılık yaşanacaktır.

$\diamond$ Türkiye'de Sakin Şehir akımına birçok ilçe tarafından ilgi duyulmaktadır. Özellikle turizm alanında yaşanan canlılık bu akımı cazip hale getirmektedir. Akım kapsamında yapılabilecek birçok çalışma bulunmaktadır. Ancak Yavaş Şehir Akımı kapsamında gelişme gösteren şehirler bu niteliğini kaybetmemelidir. Akıma üyeliği bulunan şehirlerde halkın çekindiği en önemli konu, bu akım kapsamında yaşadıkları şehrin özelliğini kaybetmesidir. Buna göre, zaman ilerledikçe ve şehirlerin tanınırlığı arttıkça nasıl bir sonuç doğacağı tahmin edilememektedir. Markalaşan bu şehirlerde nüfus artışının nereye kadar devam edeceği şehir sakinlerini düşündürmektedir.

$\diamond$ Sakin Şehirler çerçevesinde dünya kentlerinde ve Türkiye'de öne çıkan birçok özellik vardır. Buna göre, Türkiye'de Seferihisar'ın Sakin Şehir Hareketi'nde öncü bir konumu bulunması dolayısıyla incelenmesi ve özelliklerinin ortaya konması önemlidir.

$\diamond$ Seferihisar'da yaşam kalitesinin yükseltilmesi adına birçok çalışma yapılmaktadır. Bu çalışmalardaki amaç, bir yandan eski kültürün yaşatılarak yok olmaması ve gelecek nesillere aktarılması bir yandan da günlük yaşam kalitesinin artırılmasidir.

$\diamond$ Sakin Şehirlerde birçok yeni iş olanağının doğması beklenmektedir. Seferihisar'da bunun bir miktar gerçekleştiği, ekonomik yaşamın hareketlendiği ve buna bağlı olarak vergi mükellefi sayılarında da artış yaşandığı görülmektedir.

$\diamond$ Seferihisar'da Sakin Şehir Hareketi'yle beraber tarım alanında da canlılık yaşanmaktadır. Bu anlamda, çiftçi sayısındaki artış ve özellikle organik tarım alanında yapılmakta olan birçok faaliyet önemlidir.

$\diamond$ Dünyadaki Sakin Şehirlerin genel özelliğine de uygun olarak, Seferihisar'da sanayinin gelişmediği görülmektedir. 
$\diamond$ Sakin Şehir uygulamasının da katkısıyla Seferihisar'ı bir turizm markası haline getirme çabalarında ve turizm faaliyetlerinin çeşitliliğinde önemli bir artış olduğu gözlenmektedir.

$\diamond \mathrm{Bu}$ akım kapsamında Seferihisar'da, Türkiye için de önemli bir sorun olan, kadın istihdamı alanında da canlılık yaşanmaktadır.

$\diamond$ Sakin Şehir uygulamalarının, Seferihisar örneğinde de görüldüğü gibi, Türkiye'de yüksek düzeyde seyreden kayıtdışılık sorununun çözümüne de katkı vermesi beklenebilir. Bu anlamda, ekonomisi canlanan ve markalaşmaya önem veren bu şehirlerde kayıtlı iş olanaklarının artması beklenir.

$\diamond$ Dünya ve özellikle Türkiye için yenilenebilir enerji kullanımının gerekliliği ve Cittaslow uygulamasının buna verdiği önem bilinmektedir. $\mathrm{Bu}$ anlamda Seferihisar'da da yenilenebilir enerji kullanımına yönelik bazı uygulama ve projelerin gerçekleştirildiği görülmektedir.

Genel olarak ve özelde Seferihisar'daki Sakin Şehir uygulamalarından endişe duyulan yönler de vardır. Bu endişelerin başında Sakin Şehir uygulaması ile birlikte ortaya çıkan nüfus artışının ve hareketliliğinin şehrin sakinliğini bozabileceğidir.

Benzer şekilde Seferihisar ilçesinde halkın en büyük korkularından biri de bu hareketle beraber şehirde betonarme yapılaşmanın artabileceğidir. Aynı şekilde, halk tarım alanlarının tahribatından endişe duymaktadır. Buna göre, Seferihisar'a artan ilgi birçok yapılaşmayı beraberinde getirecek ve Seferihisar'ın sakin havası kalabalığa karışabilecektir.

Sakin Şehir sakinlerinin endişe duyduğu konulardan bir diğeri eski mimari yapıların yıkılıp yerlerine modern mimari yapıların yapılabilmesidir. Aslında Sakin Şehir felsefisine aykırı olan bu değişimin gerçekleşme ihtimali bu uygulama ile ilgili en çok tartışılan konulardan biridir. Bu endişenin ortadan kalkması için, Cittaslow şehirlerinde yapılaşmanın şehir mimarisine uygun devam etmesine özel önem verilmelidir. Çünkü nihayetinde bu şehirlerdeki turizm hareketliliğine temel teşkil eden en önemli özellik tarihsel ve doğal değerlere gösterilen duyarlılıktır. $\mathrm{Bu}$ anlamda, Sakin Şehir'in getirdiği canlılıkla beraber turizmde görülen hareketlilik çarpık kentleşmeye dönüşmemelidir. Bunun için, bu şehirlerde estetik yapılaşmaya özen gösterilmesi, imar düzenlemelerinin daha yakından takip edilmesi ve şehrin doğasını bozacak olan binalara izin verilmemesi gerekmektedir.

$\mathrm{Bu}$ değerlendirmeler sonucunda; özellikle organik tarım, turizm, kadın istihdamı ve yenilebilir enerji gibi alanlarda Seferihisar'da görülen olumlu gelişmelerin, daha kapsamlı bir şekilde Türkiye'deki mevcut ve gelecekte bu sisteme dahil olabilecek çok sayıdaki Sakin Şehirlerde yaşanabileceği söylenebilir. Böylece bu uygulamaların ülke genelinde yaygınlaşmasıyla Türkiye'nin ekonomik ve mali yapısına daha fazla katkı verilebilir. $\mathrm{Bu}$ anlamda devletin, Sakin Şehir 
uygulamalarını ve bu şehirlerde bu hareketin temel felsefesine uygun projeleri destekleyici ve düzenleyici yönde özel yasalar ve özel teşvik programları hazırlaması da önemlidir. Bu yasal düzenlemelerde, Sakin Şehir uygulaması sonucu ortaya çıkması muhtemel olumsuz gelişmeleri önleyici hükümler de yer almalidir.

\section{Sonuç}

Henüz çok genç bir akım olmasına rağmen Yavaş Şehir Hareketi'nin etkilediği şehirlerin sayısı her geçen gün artmaktadır. Buna göre, kurulduğu 1999 yılında 4 üyesi olan Cittaslow'un, Şubat 2017 itibariyle 30 ülkeden 230'u aşkın üyesi vardir.

Yavaş Şehir Akımı'nın, özellikle küreselleşmenin yarattığı homojen mekânlardan biri olmak istemeyip yerel kimliğini ve özelliklerini muhafaza ederek dünya sahnesinde yer almak isteyen şehirlere bir firsat sunduğu görülmektedir. Bu anlamda bu harekete üye olan şehirlerin turizm başta olmak üzere belirli alanlarda canlılık yaşadığı söylenebilir.

Şubat 2017 itibariyle Türkiye'den 14 şehir Cittaslow Birliği'ne üye olmuştur. Bunlar içinden Seferihisar'ın, Türkiye'deki Sakin Şehir Hareketi'ndeki öncü konumu dolayısıyla incelenmesinden ve özelliklerinin ortaya konmasından önemli sonuçlara ulaşılabilmektedir.

Sakin Şehir olmasıyla birlikte Seferihisar'da önemli gelişmelerin yaşandığı ve birçok projenin gerçekleştiği veya planlandığı görülmektedir. Bunlar arasında; nüfus ve vergi mükellefi sayısındaki değişim, kayıtdışılık sorununun çözümüne katkı ve ticaret ve yatırımlardaki artışla birlikte özellikle organik tarım alanındaki gelişmeler, turizm faaliyetlerinin çeşitliliğindeki artış, kadın istihdamı alanındaki canlılık ve yenilenebilir enerji kullanımına yönelik çalışmaların öne çıtı̆̆ görülmektedir.

Seferihisar örneğinde nüfus artışı ve hareketliliğin artışı ve imar düzenlemeleri ile ilgili Sakin Şehir uygulamalarından endişe duyulan bazı yönler olsa da alınacak önlemlerle bunların önüne geçilebilir.

Özellikle organik tarım, turizm, kadın istihdamı ve yenilebilir enerji gibi alanlarda Seferihisar'da görülen olumlu gelişmelerin, daha kapsamlı bir şekilde Türkiye'deki mevcut ve gelecekte bu sisteme dahil olabilecek çok sayıdaki Sakin Şehirlerde yaşanabileceği söylenebilir. Buna göre, bu uygulamaların ülke genelinde yaygınlaşmasıyla Türkiye'nin ekonomik ve mali yapısına daha fazla katkı sağlanacağı düşünülerek devletin, Sakin Şehir uygulamalarını ve bu kapsamdaki projeleri destekleyici ve düzenleyici yönde özel yasalar ve özel teşvik programları hazırlaması önemlidir. 


\section{Kaynakça}

Alptürk, E. (2015), "Kayıtdışı İstihdamın Finansal ve Vergisel Boyutu", http://kayitdisiekonomi.com/makale/detay.asp?id=33 (Erişim: 13.09.2015).

Atlas (2015), "Cittaslow Hareketine Katılan Türkiye ve Dünya Kentleri”, Atlas Dergisi, Ek Sayı: 271, İstanbul: Doğan Ofset Yayıncılık ve Matbaacılık A.Ş.

BİK (Basın İlan Kurumu) (2014), "Kayıtdışı Ekonomi Geriledi”, http://www.bik.gov.tr/kayit-disi-ekonomi-geriledi-haberi-75507/ (Erişim: 13.10.2015).

BSTB (Bilim, Sanayi ve Teknoloji Bakanlığı) (2012), KOBİ'ler ve Girişimcilerin Türk Ekonomisindeki Yeri ve Önemi, https://anahtar.sanayi.gov.tr/tr/news/kobiler-ve-girisimcilerin-turkekonomisindeki-yeri-ve-onemi/261 (Erişim: 10.02.2017).

Bowden, N. and Payne, James, E. (2010), "Sectoral Analysis of the Causal Relationship Between Renewable and Non-Renewable Energy Consumption and Real Output in the US.", Energy Sources, Part B: Economics, Planning, and Policy, 5 (4), 400-408.

Caffyn, A. (2007), "Slow Tourism”, www.tpnw.org (Erişim: 28.07.2015).

Cittaslow Seferihisar (2015), http://cittaslowturkiye.org/cittaslow-seferihisar/ (Erişim: 12.11.2015)

Cittaslow Türkiye (2015), http://cittaslowturkiye.org/uyelik-sureci-vekriterler/ (Erişim: 19.12.2015)

Cittaslow (2017-1), http://www.cittaslow.org/sites/default/files/content/page/ files/246/cittaslow_list_october_2016.pdf, (Erişim: 10.02.2017).

Cittaslow (2017-2), http://www.cittaslow.org/news/savsat-turkish-cittaslowcoordinating-committee-2017, (Erişim: 10.02.2017).

ÇSGB (Çalışma ve Sosyal Güvenlik Bakanlığı) (2013), İş Hayatı İstatistikleri, http://www.uis.gov.tr/media/1084/calisma_hayati_istatistikleri_2013.pdf (Erişim: 07.11.2015).

EIA (U.S. Energy Information Administration) (2012), Annual Energy Outlook, http://www.eia.gov/forecasts/aeo/pdf/0383.pdf (Erişim: 27.08.2015).

Erdal, L. (2012), "Türkiye'de Yenilenebilir Enerji Yatırımları ve İstihdam Yaratma Potansiyeli”, Sosyal ve Beşeri Bilimler Dergisi, 4(1), 171-181.

ETIKK (Ege Turistik İşletmeler ve Konaklama Birliği) (2013), İzmir 2013 Turizm Raporu, http://www.aktob.org.tr/pdf/IZMIR.TURIZM.RAPORU2013.pdf (Erişim: 13.11.2015). 
Gençoğlu, M.T. (2015), "Yenilenebilir Enerji Kaynaklarının Türkiye Açısından Önemi”, http://www.solar-academy.com/menuis/Yenilenebilir-EnerjiKaynaklarinin-Turkiye-Acisinda n-Onemi.005039.pdf (Erişim: 13.08.2015)

GİB (Gelir İdaresi Başkanlığı) (2014), "Seferihisar Mükellef Sayıları", http://www.gib.gov.tr (Erişim: 14.12.2015).

Gottschalk, S. (1999), "Qualiative Sociology, Speed Culture: Fast Strategies in Televised Commercial Ads", Qualitative Sociology, 22 (4), 311-329.

haberler.com (2011), http://www.haberler.com/sakin-sehir-seferihisar-gocsampiyonu-oldu-2611146-haberi (Erişim: 10.10.2015).

hurriyet.com.tr (2016), http://www.hurriyet.com.tr/turkiye-kayitdisiekonomide-birinci-40041686 (Erişim: 03.02.2016).

İTO (İzmir Ticaret Odası) (2015), Seferihisar, İzmir Ticaret Odası Yayınları, www.izto.org.tr/portals/0/27_seferİhİsar.pdf (Erişim: 10.12.2015).

Karakurt T.E. (2013), "Yaşam Kalitesi Ekseninde Şekillenen Alternatif Bir Kentsel Yaşam Modeli: Yavaş Kentleşme Hareketi", Uludağ Üniversitesi İIBF Dergisi, 32(1), 215-237.

Kaya, D. (2006), "Renewable Energy Policies in Turkey", Renewable and Sustainable Energy Reviews, 10, 152-163.

Kostulska, E.G, Holowiecka, B. and Kwiatkowski, G. (2011), "Cittaslow International Network: An Example of a Globalization Idea", In The Scale of Globalization: Think Globally, Act Locally, Change Individually in the 21st Century, 186-192. Ostrava: University of Ostrava, 2011, https://repozytorium.umk.pl/bitstream/handle/item/

615/186-192_Grzelak-Kostulska-Holowiecka-Kwiatkowski.pdf?sequence=1 (Erişim: 10.02.2017).

Kundera, M. (2008), Yavaşlık, (Çev.: Özdemir İnce), 13. Baskı, İstanbul: Can Yayınları.

KTB (Kültür ve Turizm Bakanlığ1) (2007), Türkiye Turizm Stratejisi 2023 Eylem Planı 2007-2013, https://www.kultur.gov.tr/Eklenti/906, ttstratejisi2023pdf. (Erişim:05.01.2017)

KTB (Kültür ve Turizm Bakanlığı) (2015), "Türkiye Mavi Bayraklı Plaj Sayısında Zirveye Oynuyor", http://basin.kulturturizm.gov.tr/TR,138603/turkiyemavi-bayrakli-plaj-sayisinda-zirveye-oynuyor.html (Erişim: 12.07.2015).

Miele, M. (2008), "Cittaslow: Producing Slowness Against the Fast Life", Space and Polity, 12 (1), 135-156. 
Uluslararası Ekonomi ve Yenilik Dergisi, 3 (1) 2017, 47-72

Newman, P. ve Jennings, I. (2008), Cities as Sustainable Ecosystems: Principles and Practices, USA, Washington: Island Pres, https://parfikh.files.wordpress.com/ 2012/01/cities-as-sustainable-ecosystem.pdf (Erişim: 02.08.2015).

nufusu.com (2017), www.nufusu.com/ilceleri/izmir-ilceleri-nufus (Erişim: 10.02.2017).

Parkins, W. (2004), "Out of the Time Fast Subjects and Slow Living", Time \& Society, 13(2/3), 363-382.

Prezi (2013), "Pazar Konusunda Geniş Kitlelere Ulaşan Seferihisar Sana", https://prezi.com/hil4r7k8cwrc/pazar-konusunda-cok-genis-kitlelere-ulasanseferihisar-sana/ (Erişim: 10.02.2017)

Radstrom, S. (2011), "A Place Sustaining Framework for Local Urban Identity: An Introduction and History of Cittaslow", Italian Journal of Planning Practice, 1 (1), 312-393.

Savaşır, R. (1999), “Türkiye ve Avrupa Birliği Ülkelerinde Küçük ve Orta Boyutlu İşletmeler Açısından İstihdam Politikaları”, http://www.kamuis.org.tr/pdf/turkiyeabrebii.pdf (16.11.2015).

Seferihisar Belediyesi (2015), Yenilenebilir Enerji ve Çevre Teknolojiler Hibe Programı, www.seferihisar.bel.tr (Erişim: 17.07.2015).

seferihisar.bel.tr (2016), http://seferihisar.bel.tr/seferihisar-plajlari-mavibayraklarla-donandi/ (Erişim: 21.01.2017).

seferihisar.com (2015), seferihisar.com/seferihisar-tarimin-festival-sehriolacak/ (Erişim: 24.12.2015).

seferihisar.com (2017), www.seferihisar.com/mandalinalar-kurutuldu-degeri5-kat-artti/ (Erişim: 10.02.2017).

seferipazar.com (2017), www.seferipazar.com (Erişim: 10.02.2017).

Sezgin, M. ve Ünüvar, Ş. (2011), Sürdürülebilirlik ve Şehir Pazarlaması Ekseninde Yavaş Şehir, Konya: Çizgi Kitabevi.

Sungur, Z. (2013), “Türkiye'nin Sakin Şehirlerindeki Kadın Girişimciliğine Sosyolojik Bir Bakış", International Conference on Eurasian Economies Session 3c: Girişimcilik, 17.10.2015.

Sustainable Cities (2015), http://www.dac.dk/en/dac-cities/sustainable-cities/ (Erişim: 02.11.2015).

Şahinkaya, S. (2010), “Bir Yerel Kalkınma Modeli: Cittaslow ve Seferihisar Üzerine

Değerlendirmeler", http://www.bagimsizsosyalbilimciler.org/Yazilar_Uye/ SahinTem10.pdf (Erişim: 10.10.2015). 
TÜRKONFED

(2014),

Faaliyet

Raporu,

http://turkonfed.org/Files/ContentFile/turkonfed-2014-faaliyet-raporu.pdf (Erişim: 03.07.2015).

TÜİK (2013), http://www.tuik.gov.tr/PreHaberBultenleri.do?id=13532 (Erişim: 12.03.2016).

TÜIK (2015-1), http://www.tuik.gov.tr/PreHaberBultenleri.do?id=18636 (Erişim: 10.02.2017).

TÜİK (2015-2), Toplumsal Cinsiyet İstatistikleri 2014, http://www.tuik.gov.tr/Icerik

Getir.do?istab_id=294 (10.02.2017).

Wikipedia

Yavaş

Hareketi, https://tr.wikipedia.org/wiki/Yavaş_Hareketi (Erişim: 6.11.2015).

Yeni Asır Gazetesi (2015), "Seferihisar Mandalina Şenliğine Hazır", http://www.yeniasir.com.tr/kenthaberleri/2015/11/13/seferihisar-mandalinasenligine-hazir (Erişim: 12.12.2015). 